\title{
PENINGKATAN HASIL BELAJAR BAHASA INGGRIS MELALUI IMPLEMENTASI MODEL PEMBELAJARAN MURDER PADA SISWA KELAS IX SMP N 7 MATARAM, NUSA TENGGARA BARAT
}

\author{
Suherni \\ SMP N 7 Kota Mataram, Nusa Tenggara Barat \\ busuherni.lombok@gmail.com
}

\begin{abstract}
This study aims to determine the improvement of English learning outcomes through the implementation of the MURDER learning model for Class IX students of SMP N 7 Mataram, West Nusa Tenggara. The research was conducted in October 2020 in Class IX SMP N 7 Mataram with two cycles of Classroom Action Research (CAR). Based on the research, it can be seen that the application of the MURDER learning model can improve the English learning outcomes of Class IX students at SMP N 7 Mataram. During the first cycle of CAR, 80.95\% of students had completed and $19.05 \%$ of students had not completed it. There was an increase of $47.62 \%$ of students completing the first cycle (from $33.33 \%$ of students completing before the CAR to $80.95 \%$ of students completing the first cycle of CAR). During the second cycle of CAR, there were $90.48 \%$ of students who had completed it and $9.52 \%$ of the students had not completed it. There was an increase of $9.53 \%$ of students completing the second cycle (from $80.95 \%$ of students completing the first CAR to $90.48 \%$ of students completing the second cycle of CAR).
\end{abstract}

Keywords: English Learning Outcomes, MURDER Learning Model, Mataram City

Abstrak: Penelitian ini bertujuan untuk mengetahui peningkatan hasil belajar Bahasa Inggris melalui implementasi model pembelajaran MURDER pada siswa Kelas IX SMP N 7 Mataram, Nusa Tenggara Barat. Penelitian dilakukan pada bulan Oktober 2020 di Kelas IX SMP N 7 Mataram dengan dua siklus Penelitian Tindakan Kelas (PTK). Berdasarkan penelitian dapat diketahui bahwa penerapan model pembelajaran MURDER dapat meningkatkan hasil belajar Bahasa Inggris siswa Kelas IX di SMP N 7 Mataram. Saat siklus pertama PTK terdapat sebanyak $80,95 \%$ siswa tuntas dan sebanyak $19,05 \%$ siswa belum tuntas. Terdapat peningkatan $47,62 \%$ siswa yang tuntas pada siklus pertama (dari 33,33\% siswa tuntas saat sebelum PTK menjadi 80,95\% siswa tuntas pada PTK siklus pertama). Saat siklus kedua PTK terdapat sebanyak $90,48 \%$ siswa tuntas dan sebanyak $9,52 \%$ siswa belum tuntas. Terdapat peningkatan $9,53 \%$ siswa yang tuntas pada siklus kedua (dari 80,95\% siswa tuntas pada PTK pertama menjadi 90,48\% siswa tuntas pada PTK siklus kedua).

Kata Kunci: Hasil Belajar Bahasa Inggris, Model Pembelajaran MURDER, Kota Mataram

\section{PENDAHULUAN}

Pembelajaran merupakan suatu sistem instruksional yang mengacu pada seperangkat komponen yang saling bergantung satu sama lain untuk mencapai tujuan. Sebagai sebuah sistem, pembelajaran meliputi suatu komponen, dimana 
komponen pembelajaran tersebut akan mempengaruhi jalannya pembelajaran (Hamruni, 2012). Salah satu komponen penting yang harus diperhatikan secara terus menerus dalam proses pembelajaran adalah guru. Salah satu tugas dan tanggung jawab guru adalah transfer of knowledge, yakni proses mentransfer ilmu pengetahuan, informasi, pengalaman dan pelajaran dari berbagai sumber kepada penerima. Dalam dunia pendidikan transfer of knowledge sangat bemanfaat untuk mencapai tujuan pendidikan yaitu untuk meningkatkan kemampuan dan ketrampilan siswa. Proses transfer knowledge akan berjalan dengan baik apabila terjalin komunikasi yang baik antara guru dan siswa. Guru dalam menyampaikan pelajaran perlu mengamati kondisi siswa, kebutuhan siswa dan gaya belajar masing-masing siswa sehingga mampu menentukan model pembelajaran yang tepat dan menciptakan pembelajaran yang menyenangkan sesuai dengan kebutuhan siswa (Deporter, 2008).

Model Pembelajaran berasal dari dua kata yaitu model dan pembelajaran. Model adalah bentuk mode, bentuk rupa, bentuk contoh (Partanto dan Barri, 1994). Model merupakan kerangka konseptual yang digunakan sebagai pedoman dalam melakukan suatu kegiatan (Zayani dan Majid, 2005). Sedangkan pembelajaran atau pengajaran adalah upaya untuk membelajarkan siswa (Uno, 2011). Untuk mencapai tujuan pembelajaran guru diperlukan model pembelajaran yang tepat, sesuai dengan kondisi siswa, karakteristik mata pelajaran dan fasiltias yang tersedia (Erman, 2008).

Model pembelajaran ialah kerangka konseptual dan prosedur yang sistematik dalam mengorganisasikan pengalaman belajar untuk mencapai tujuan belajar tertentu, dan berfungsi sebagai pedoman bagi perancang pengajaran dan para guru dalam merencanakan dan melaksanakan aktivitas belajar mengajar (Zayani dan Majid, 2005). Banyak faktor yang mempengaruhi keberhasilan kegiatan pembelajaran sehingga perlu pemahaman atas semua faktor yang ada agar tujuan pendidikan yang terangkum dalam hasil belajar siswa dapat dicapai sesuai dengan yang diharapkan. Kesulitan belajar dapat saja datang dari siswa tetapi juga disebabkan oleh faktor lingkungan belajarnya. Kesanggupan siswa untuk memahami pelajaran, ketekunan siswa dan kesempatan yang disediakan untuk 
mempelajari ruang lingkup materi yang ditentukan juga merupakan faktor yang mempengaruhi hasil belajar.

Berdasarkan pengamatan dapat diketahui bahwa hasil belajar mata pelajaran Bahasa Inggris siswa kelas IX di SMP N 7 Mataram masih kurang memuaskan. Hal ini dapat diketahui dari banyaknya siswa yang belum mencapai nilai Kriteria Ketuntasan Minimal (KKM). Banyaknya jumlah siswa yang memperoleh nilai di bawah KKM dikarenakan kurangnya semangat belajar siswa di dalam mengikuti proses pembelajaran di kelas. Hal ini dapat dilihat dari tanda-tanda yang timbul seperti: siswa sering menguap ketika guru sedang menjelaskan materi pelajaran di depan kelas, siswa sering melamun saat belajar, dan siswa cenderung pasif dalam belajar. Beberapa usaha telah dilakukan peneliti untuk mengatasinya siswa yang kurang serius dalam mengikuti proses pembelajaran dengan cara memberi peringatan kepada siswa yang suka menguap dan melamun dalam belajar, tetapi hasil yang diperoleh tidak dapat juga meningkatkan motivasi belajar siswa serta hasil belajar siswa.

Untuk mengatasi permasalahan di atas diperlukan suatu penerapan model pembelajaran yang kreatif, inovatif, dan tepat serta sesuai dengan kondisi kelas. Salah satu model pembelajaran yang dapat diterapkan adalah model pembelajaran “MURDER", yaitu: Mood (Suasana Hati), Understand (Pemahaman), Recall (Pengulangan), Digest (Penelaahan), Expand, (Pengembangan), Review, (Pelajari Kembali). Andriani dan Utama (2017) menyatakan bahwa bahwa pembelajaran yang menggunakan model pembelajaran MURDER terhadap kemampuan berpikir kritis matematis siswa kelas VIII SMP Lampung Tengah lebih baik dari pembelajaran konvensional. Pelaksanaan pembelajaran ini diawali dengan membangun suasana hati siswa agar memiliki perasaan dan pemikiran positif terhadap matematika, memahami materi matematika, mengingat kembali materi yang telah dipelajari, Mendeteksi kesalahan yang dilakukan, mengelaborasi pengetahuan, dan mengulas kembali apa yang telah dikerjakan (Sumartini, 2018)

Berdasarkan hal tersebut maka perlu dilakukan penelitian untuk mengetahui peningkatan hasil belajar Bahasa Inggris melalui implementasi model pembelajaran MURDER pada siswa Kelas IX SMP N 7 Mataram, Nusa Tenggara Barat.

\section{METODE}


Penelitian ini dilaksanakan di kelas IX SMP N 7 Mataram pada semester ganjil tahun pelajaran 2020/2021, yaitu bulan Oktober 2020. Penelitian ini merupakan Penelitian Tindakan Kelas (PTK) yaitu suatu penelitian yang dilakukan di dalam kelas, guna memperbaiki proses pembelajaran yang dilakukan oleh guru. Menurut Arikunto (2006), Penelitian Tindakan Kelas bertujuan untuk meningkatkan kemampuan guru atau peneliti karena dilakukan oleh guru sendiri yang bersifat reflektif yang bertujun untuk meningkatkan hasil belajar siswa dalam mata pelajaran Bahasa Inggris. Pada penelitian ini digunakan model pembelajaran MURDER.

Berikut diuraikan prosedur penelitian yang telah dilaksanakan dalam dua siklus pada penelitian ini:

\section{Perencanaan}

Penelitian ini dilaksanakan dalam dua siklus. Masing-masing siklus dua pertemuan. Penetapan materi pembelajaran Bahasa Inggris berupa Rencana Pelaksanaan Pembelajaran (RPP) dan penetapan alokasi waktu pembelajarannya. Tahap-tahapnya antara lain: pengembangan silabus, menyiapkan Rencana Pelaksanaan Pembelajaran (RPP), menyiapkan lembar observasi aktivitas guru dan siswa, dan menyiapkan evaluasi siswa.

\section{Tahap Pelaksanaan}

Pada tahap pelaksanaan ini hal-hal yang akan dilakukan antara lain adalah sebagai berikut: pendahuluan yang terdiri dari absensi siswa dan mengkondisikan siswa dan kegiatan inti. Pelaksanaan pembelajaran sesuai RPP dengan penerapan model pembelajaran MURDER dengan langkah-langkah sebagai berikut :

1) Guru membentuk kelompok yang terdiri dari 6 orang siswa.

2) Guru menyuruh tiap kelompok membaca materi yang telah dibagikan.

3) Guru menyuruh perwakilan kelompok menyampaikan materi yang telah dibaca kepada anggota kelompok lainnya.

4) Guru menyuruh anggota lain menemukan setiap kesalahan, kelalaian, atau informasi yang tidak perlu dan mendiskusikannya dengan penyampai materi. 
5) Guru menyuruh siswa menghubungkan ide yang ada pada wacana dengan pengalaman yang dimilikinya

6) Guru menyuruh siswa ketika seluruh teks telah selesai, pasangan memadukan pikiran mereka kemudian meringkas keseluruhan teks.

7) Melakukan penilaian dan evaluasi.

\section{Tahap Observasi}

Tahap observasi yang dilakukan dalam penelitian ini dengan menggunakan format pengamatan yang telah disediakan. Hal-hal yang diamati adalah aktivitas guru dan aktivitas siswa.

\section{Refleksi}

Tahap refleksi meliputi proses analisis hasil pembelajaran dan penyusunan rencana perbaikan untuk pembelajaran berikutnya.

1) Mencatat hasil pengamatan.

2) Mengevaluasi hasil pengamatan.

3) Menganalisis tingkat pemahaman siswa dan hasil pembelajaran.

4) Membuat perbaikan tindakan untuk pembelajaran berikutnya.

Pada tahap observasi, peneliti melakukan pengamatan terhadap semua proses tindakan yang terjadi dalam pembelajaran. Kemudian pada tahap refleksi dilakukan pengevaluasian siklus yang bertujuan untuk memperbaiki proses kegiatan pada siklus berikutnya.

Setelah data terkumpul, langkah selanjutnya adalah analisis data. Analisis data adalah proses mencari dan menyusun secara sistematis data yang diperoleh dari hasil wawancara, catatan lapangan dan dokumentasi, dengan mengorganisasikan data kedalam kategori, menjabarkan kedalam unit-unit, melakukan sintesa, menyusun ke dalam pola, memilih mana yang penting dan yang akan dipelajari dan membuat kesimpulan sehingga mudah dipahami oleh diri sendiri maupun orang lain (Sugiyono, 2009). Analisis data yang digunakan dalam penelitian ini adalah analisis deskriptif-analitik, yakni menjabarkan dan 
menganalisis secara kritis segala fenomena yang ditemukan di lapangan. Sehingga menghasilkan kesimpulan penelitian yang obyektif.

\section{HASIL DAN PEMBAHASAN}

Penelitian ini dilaksanakan di kelas IX B SMP N 7 Mataram semester ganjil Tahun Ajaran 2020/2021 dengan jumlah siswa 42 orang yang terdiri dari 20 orang siswa perempuan dan 22 orang siswa laki-laki yang mempunyai kemampuan heterogen. Penelitian ini dibagi ke dalam dua siklus.

Tabel 1. Hasil Belajar Siswa Sebelum PTK

\begin{tabular}{ll}
\hline Nilai Tertinggi & $\mathbf{9 4}$ \\
\hline Nilai Terendah & 60 \\
\hline Rata-Rata & 73,21 \\
\hline Tuntas & 14 orang \\
\hline Tidak Tuntas & 28 orang
\end{tabular}

Sumber data: Hasil Penelitian Peneliti (2020)

Berdasarkan tabel tersebut dapat diketahui bahwa sebelum pelaksanaan PTK terdapat sebanyak 33,33\% siswa tuntas dan sebanyak 66,66\% siswa belum tuntas.

Tabel 2. Hasil Belajar Siswa Siklus Pertama dan Siklus Kedua

\begin{tabular}{lll}
\hline Siklus & Siklus Pertama & Siklus Kedua \\
\hline Nilai Tertinggi & 95 & 95 \\
\hline Nilai Terendah & 67 & 67 \\
\hline Rata-Rata & 78,54 & 80,28 \\
\hline Tuntas & 34 orang & 38 orang \\
\hline Tidak Tuntas & 8 orang & 4 orang
\end{tabular}

Sumber data: Hasil Penelitian Peneliti (2020)

Berdasarkan tabel tersebut dapat diketahui bahwa saat siklus pertama PTK terdapat sebanyak $80,95 \%$ siswa tuntas dan sebanyak 19,05\% siswa belum tuntas. Terdapat peningkatan $47,62 \%$ siswa yang tuntas pada siklus pertama (dari 33,33\% siswa tuntas saat sebelum PTK menjadi 80,95\% siswa tuntas saat PTK siklus pertama). Berdasarkan tabel tersebut dapat diketahui bahwa saat siklus kedua PTK terdapat sebanyak 90,48\% siswa tuntas dan sebanyak 9,52\% siswa belum tuntas. Terdapat peningkatan $9,53 \%$ siswa yang tuntas pada siklus kedua (dari $80,95 \%$ 
siswa tuntas pada PTK pertama menjadi $90,48 \%$ siswa tuntas pada PTK siklus kedua).

Hal ini menunjukkan bahwa siswa dapat mengikuti proses pembelajaran Bahasa Inggris melalui penerapan model MURDER dengan sangat baik. Penerapan model pembelajaran MURDER dapat memperkuat pemahaman siswa karena siswa harus mengemukakan, menjelaskan, memperluas, dan mencatat ide-ide utama dari teks secara verbal. Dalam hal ini, keterampilan memproses informasi lebih diutamakan. Pemprosesan informasi menuntut keterlibatan metakognisi berpikir dan membuat keputusan berdasarkan pemikiran. Selain itu, langkah 'menghubungkan dengan pengalaman' memungkinkan siswa untuk menghubungkan informasi-informasi yang cukup penting dengan pengetahuan yang telah dimiliki sebelumnya. MURDER merupakan model pembelajaran yang diadaptasi dari buku Hayes yang merupakan gabungan dari kata mengenai langkahlangkah pembelajaran The Acronym MURDER stand fir the six paris of Desereau et al's study system: Mood, Understand, Recall, digest, Expand, and Review. Dalam pembelajaran ini memiliki beberapa keunggulan diantaranya: (1) Menciptakan suasana belajar yang menyenangkan, (2) Membantu para siswa dalam mengembangkan sistem belajar yang efektif dan efesien, dan (3) Menunjang keaktifan siswa (Hayes, 1940).

Pada pertemuan pertama dengan menerapkan model pembelajaran MURDER seluruh siswa tidak terlihat antusias. Hal ini terjadi karena peserta didik tidak terbiasa untuk berpikir dan menemukan sendiri. Karena sebelumnya peserta didik terbiasa menggunakan pembelajaran konvensional yang tidak menuntut peserta didik untuk berpikir dalam menemukan konsep, serta kurangnya referensi dalam tahap expand (pengembangan). Pada petemuan kedua siswa mulai terbiasa dalam proses pembelajaran MURDER namun dalam tahap Digest dan Expand peserta didik masih kesulitan dalam hal memecahkan masalah pada soal karena siswa tidak mau untuk mencari dari sumber lain, namun apabila disuruh mencari menggunakan alat bantu elektronik peserta didik lebih senang. Pada tahap ini peserta didik sudah mulai aktif dalam bertanya hal yang belum dipahami. Pada pertemuan ketiga setelah diberikannya kebebasan untuk mencari sumber lain peserta didik lebih antusias dalam proses pembelajaran dan dalam bertanya maupun menjawab 
pertanyaan yang diajukan kepada guru, serta setiap tahap pembelajaran peserta didik lebih aktif dalam setiap kelompoknya.

Berdasarkan proses pembelajaran yang telah dilakukan terlihat bahwa peserta didik lebih banyak mendapatkan informasi sesuai usaha mereka masing-masing, dan lebih banyak pertanyaan yang muncul sehingga proses pembelajaran lebih menyenangkan. Selain itu, setiap anggota aktif dalam proses pembelajaran, karena masing-masing anggota kelompok mempunyai tugas masing-masing dan juga membantu angota kelompok yang kurang paham dengan materi yang diberikan.

Selain itu, dalam proses pembelajaran menggunakan model pembelajaran MURDER yang diterapkan menjadikan peserta didik memiliki aktivitas belajar yang lebih banyak. Peserta didik juga dapat saling berbagi pengetahuan melalui massing-masing kelompok yang diberikan sehingga memudahkan guru untuk mengecek sejauh mana kemampuan penguasaan materi peserta didik. Kegiatan pembelajaranpun tidak berpusat pada guru, tetapi dituntut keaktifan peserta didik sehingga minat peserta didik dalam pembelajaran lebih besar. Selain itu model pembelarana MURDER sangat cocok bagi kelas dengan siswa heterogen dan beragam baik dari aspek jenis kelamin maupun kemampuan siswa (Herdianto, Sudhita, \& Sedanayasa, 2014)

Pada kegiatan awal guru berusaha membangun Mood dari siswa dengan mengecek kebersihan kelas dan memotivasi siswa dengan cerita-cerita dan informasi yang terkait dengan materi pelajaran. Tahap berikutnya adalah pemahaman (Understand) di mana siswa membaca dan memahami materi pelajaran dengan mencermati aspek penting yang ada dari materi pelajaran, kemudian tahap mengulang (Recall) siswa memberikan sajian lisan dengan mengulang materi yang sudah dibaca dan dipahami. Digest atau menelaah adalah tahap di mana siswa memberikan koreksi dari materi yang sudah dipahami, tahap berikutnya adalah siswa mengembangkan (Expand) materi dengan memberikan contoh atau aplikasi materi yang telah dipahami dalam kehidupan sehari-hari, dan mengemukakan beberapa pertanyaan terkait materi yang dibahas. Tahap terkahir adalah merangkum (Review) kembali hasil pekerjaan berdasarkan hasil belajar selama proses pembelajaran dan menyimpulkannya. Penerapan model pembelajaran MURDER dapat mempengaruhi aktivitas siswa dalam mengikuti proses pembelajaran. Siswa 
yang aktif dapat menciptakan suasana pembelajaran di kelas menjadi lebih menyenangkan. Terciptanya kondisi belajar yang menyenangkan dapat meningkatkan daya serap siswa terhadap meteri ajar yang telah dijelaskan oleh guru, sehingga dapat disimpulkan bahwa penerapan model pembelajaran MURDER dapat meningkatkan hasil belajar Bahasa Inggris siswa. Sehingga penerapan model pembelajaran MURDER dapat meningkatkan hasil belajar Bahasa Inggris siswa kelas IX B SMP N 7 Mataram.

\section{SIMPULAN}

Berdasarkan penelitian dapat diketahui bahwa penerapan model pembelajaran MURDER dapat meningkatkan hasil belajar Bahasa Inggris siswa Kelas IX di SMP N 7 Mataram. Saat siklus pertama PTK terdapat sebanyak 80,95\% siswa tuntas dan sebanyak $19,05 \%$ siswa belum tuntas. Terdapat peningkatan $47,62 \%$ siswa yang tuntas pada siklus pertama (dari 33,33\% siswa tuntas saat sebelum PTK menjadi 80,95\% siswa tuntas pada PTK siklus pertama). Saat siklus kedua PTK terdapat sebanyak 90,48\% siswa tuntas dan sebanyak 9,52\% siswa belum tuntas. Terdapat peningkatan 9,53\% siswa yang tuntas pada siklus kedua (dari $80,95 \%$ siswa tuntas pada PTK pertama menjadi 90,48\% siswa tuntas pada PTK siklus kedua).

\section{DAFTAR RUJUKAN}

Andriani, S. dan W. Utama. 2017. Pengaruh Model Pembelajaran MURDER (Mood, Understand, Recall, Digest, Expand, Review) Terhadap Kemampuan Berpikir Kritis Matematis Siswa. Seminar Matematika Dan Pendidikan Matematika UNY 2017: 689-696.

Arikunto, S. S. 2006. Penelitian Tindakan Kelas. Jakarta: Bumi Aksara.

Deporter, B. 2008. Quantum Teaching (Mempraktekkan Quantum Learning di Ruang-Ruang Kelas). Bandung: Kaifa.

Erman. (2008). Model Belajar dan Pembelajaran Berorientasi Kompetensi Siswa. Jurnal Pendidikan Dan Budaya, 5(2), 11-12.

Herdianto, K., Sudhita, I. W. R., \& Sedanayasa, G. (2014). Pengaruh model pembelajaran MURDER terhadap pemahaman konsep IPA siswa kelas V SD dI gugus I kecamatan Buleleng. Mimbar Pgsd, 2(1), 1-10. Retrieved from http://ejournal.undiksha.ac.id/index.php/JJPGSD/article/view/4349 
Hamruni. 2012. Strategi Pembelajaran. Yogyakarta: Insan Madani.

Hayes, J.R. 1940. The Complete Problem Solver. United States of America.

Partanto, P.A. dan D.A. Barri. 1994. Kamus Ilmiah Popular. Surabaya: Arloka.

Sumartini, T. S. (2018). Peningkatan Kemampuan Pemecahan Masalah Matematis Siswa melalui Pembelajaran Berbasis Masalah. Mosharafa: Jurnal Pendidikan Matematika, 5(2), 148-158. https://doi.org/10.31980/mosharafa.v5i2.270

Uno, H.B. 2011. Model Pembelajaran Menciptakan Proses Belajar Mengajar yang Kreatif dan Efektif. Jakarta: Bumi Aksara.

Zayani, A. dan A. Majid. 2005. Tadzkirah Pembelajaran Pendidikan Agama Islam Berdasarkan Pendekatan Konseptual. Jakarta: Raja Grafindo Persada. 